carefully kept throughout the various moves of the (Royal) Medico-Psychological Association before it became the College and settled in a permanent headquarters in Belgrave Square. Paperwork from other (Royal) Medico-Psychological Association bodies was not kept so systematically and this article will describe what has survived.

\section{Special Committees}

The newly founded Association lost no time in setting up special committees. The first of these, the Registers and Tables Committees, was appointed at the first annual meeting in 1841 and reported the following year. Many other committees followed; some produced reports that were printed in the JMS or bound into the Council minute books; others produced reports that have disappeared and others just disappeared without apparently reporting or even meeting. Records of two committees are in the archives, namely the Medical Planning Committee, 1944-1945, which have been used for a history of the National Health Service, and the Appeal Committee, 1971-1985. Records of the Special Committee on Unethical Psychiatric Practices are also held and are awaiting sorting. In recent years the College has developed a records management system and record keeping is becoming more structured.

\section{Sections}

The College's Specialist Sections (now Faculties) developed from 1928 onwards from Research
Committee Sub-Committees, and became Specialist Sections when the (Royal) Medico-Psychological Association became the College. Minutes from most Sections (Faculties) are in the archives, although the earliest of these minutes dates only from the 1940s.

\section{Divisions}

College Divisions date from the early 1890 s although there were regular meetings in Ireland and Scotland before then. The modern Divisions retain their own records. Of the pre-1972 divisions, minutes of the South-East Division, 1897-1971; of the South-West Division. 19551971; and of the Northern and Midland Division. 1964-1971; are in the archives and there are also small files relating to the Indian Division that existed from 1936 to 1948 and to the New Zealand branch that was proposed in 1928 . Records of the Scottish Division from 1869 are in Edinburgh University Library, but the whereabouts of early records of the South-West Division (founded in 1894) the Northern and Midland Division (founded in 1897) and of any records of the Irish Division is unknown.

I am in the College on Wednesdays, Thursdays and Fridays and would be pleased to answer any questions about the archives. Suggestions or information about any relevant archival material would be welcomed.

Margaret Harcourt Williams, College Archivist, Royal College of Psychiatrists, 17 Belgrave Square, London, SW1X 8PG

\title{
Procedure for the nomination of examiners
}

As part of the procedures to assist in standardisation of the Membership Examination of the Royal College of Psychiatrists, the Court of Electors endorsed recently a proposal approved by the Examinations SubCommittee defining the criteria recommended for aspirants wishing to become members of the Board of Examiners of the Royal College of Psychiatrists. These criteria are given below.

\section{MRCPsych Part I Board of Examiners}

To be eligible to become a member of this Board, a doctor must have held a consultant or equivalent post in general adult or old age psychiatry for at least two years.

\section{MRCPsych Part II Board of Braminers}

To be eligible to become a member of this Board, a doctor must have held a consultant or 
equivalent post in psychiatry for at least five years.

The following criteria are used for the appointment of Examiners to either Board:

(a) must be registered for CPD;

(b) must be practising in an appropriate clinical area of psychiatry and seeing patients on a regular basis;

(c) must have had some experience of teaching at a postgraduate level;

(d) must have current or recent experience of training doctors undergoing basic level training in psychiatry.

Examiners can only be nominated by one of the following:

(a) member of the Court of Electors;

(b) a Professor of Psychiatry;

(c) a Regional Adviser;

(d) Chairmen of the Divisions, Faculties and Sections of the College:

(e) Chairmen of Regional Training Committees.
A Nomination Form has to be completed and signed by an individual from one of the categories listed above. Forms are avallable from: Assistant to the Head of Examination Services, The Examination Services Department, Royal College of Psychiatrists, 17 Belgrave Square, London SW1X 8PG. Tel: 0171235 2351, ext. 252.

The nominee should attach a full Curriculum Vitae to the form, which should provide the information set out in the criteria listed above.

The form and the Curriculum Vitae should be returned to the Chief Examiner at the address above.

Eligible nominations are then considered by the Court of Electors.

The Court of Electors decides which Examiners are to be appointed to each Board.

S. P. Tyrer, Chief Examiner, Royal College of Psychiatrists, 17 Belgrave Square, London SWIX 8PG

\section{Elections to the General Medical Council}

Psychiatrists have a crucial role to play in assisting the work of the General Medical Council, particularly in relation to its Health Procedures. There are, at present, three psychiatrists on the General Medical Council, out of a total of 102.

Voting papers for election to the General Medical Council will be dispatched to registered doctors in England, Scotland, Wales and Northern Ireland in May 1999. You may wish to know that the following psychiatrists will be standing for election.

Dr Mark Aveline, Consultant Psychotherapist, Nottingham Psychotherapy Unit.

Dr R. N. Chitty, Consultant Psychiatrist, West Cheshire Hospital.

Dr Anwar E1-Komy, Consultant Psychiatrist, Forston Clinic, Dorchester.

Dr Doug Fowlie, Consultant Psychiatrist and Honorary Clinical Senior Lecturer, Royal Cornhill Hospital, Aberdeen.
Professor Bamid Ghodse, Professor of Psychiatry. St George's Medical School, London.

Dr Pearl Eettiaratchy, Consultant Psychiatrist in Old Age Psychiatry, Winchester (currently a member of the General Medical Council - eligible for re-election).

Dr Andrew MacAulay, Consultant Psychiatrist, Wrexham Park Hospital.

Dr J. McDonald, Consultant Psychiatrist, Queen Elizabeth Hospital, Gateshead.

Stephen O'Brien, Clinical Director, University Hospital, Aintree.

Professor Andrew Sims, Professor of Psychiatry, University of Leeds (currently a member of the General Medical Council-eligible for reelection).

Dr Paul Srinivasan, Consultant Psychiatrist, St George's Hospital, Stafford.

Vanessa Cameron, The Secretary, Royal College of Psychiatrists, 17 Belgrave Square, London SW1X 8PG 